UPPSALA UNIVERSITET
Working Paper 2006:15

Department of Economics

Does Unemployment Hysteresis Equal Employment Hysteresis?

Magnus Gustavsson och Pär Österholm 
Department of Economics

Uppsala University

P.O. Box 513

SE-751 20 Uppsala

Sweden

Fax: +46184711478
Working paper 2006:15

July 2006

ISSN 1653-6975

Does Unemployment Hysteresis Equal Employment Hysteresis?

Magnus Gustavsson And PÄr Österholm

Papers in the Working Paper Series are published on internet in PDF formats.

Download from http://www.nek.uu.se

or from S-WoPEC http://swopec.hhs.se/unnewp/ 


\title{
Does Unemployment Hysteresis Equal Employment Hysteresis?
}

\author{
Magnus Gustavsson ${ }^{\#}$ \\ Department of Economics, Uppsala University \\ and \\ Pär Österholm* \\ Department of Economics, Uppsala University and Sveriges Riksbank
}

July 10, 2006

\begin{abstract}
This paper investigates if conclusions regarding labour market hysteresis differ depending on whether employment or unemployment rates are studied. Applying a range of unit-root tests to monthly data from Australia, Austria, Canada, Finland, Sweden, the U.K. and the U.S., we find results for employment rates that contrast those based on unemployment rates. In particular, rather than the mixed evidence for hysteresis found using unemployment rates, employment rates result in unequivocal evidence of hysteresis in Australia, Canada and the U.S.. These findings cast doubt on previous conclusions in the literature.
\end{abstract}

JEL Classification: C22, E24, J21

Keywords: Labour market, Persistence, Unit root test

\footnotetext{
*We are grateful to Meredith Beechey for valuable comments. Financial support from Jan Wallander's and Tom Hedelius' foundation is gratefully acknowledged.

\# Department of Economics, Uppsala University, Box 513, 75120 Uppsala, Sweden e-mail: magnus.gustavsson@nek.uu.se Phone: +46 184711103 Fax: +46 184711478

* Department of Economics, Uppsala University, Box 513, 75120 Uppsala, Sweden e-mail: par.osterholm@nek.uu.se Phone: +1 2023784135 Fax: +46 184711478
} 


\section{Introduction}

Theories of labour market hysteresis have received a great deal of attention and for good reasons. The main prediction of these theories - that one-time shocks to the labour market have permanent effect - has important implications for how labour markets function and for the long-run potentials of economic policy. Accordingly, numerous empirical studies have investigated whether one-time shocks to labour markets have permanent effect by testing for a unit root in time series of unemployment rates. ${ }^{1}$

We argue, however, that there are two serious drawbacks of testing for hysteresis using unemployment rates. First, as shown by Clark and Summers (1979), Feldstein and Ellwod (1982), Coleman (1989) and Brandolini et al. (2006), it is difficult to draw the line between who is unemployed and who is out of the labour force. This separation should ideally be made according to who wants a job and who does not. However, official statistics have great difficulty accurately measuring this separation since only individuals fulfilling some criteria of actively searching for a job are entered as unemployed. A second and related drawback of previous studies is the explicit or implicit assumption of a one-to-one relationship between unemployment and employment. This is a questionable assumption since participation rates vary in a way that need not be stationary. Imagine an economy in which a large, one-time negative shock has a permanent effect not only on employment but also on the participation rate. This could for instance be the case if the increase in joblessness is accompanied by increased long-term unemployment which in turn triggers individuals to give up on their future job prospects, decrease their active job-search and leave the labour force. Clearly, in such a scenario, a shock with permanent effect on employment need not impart a unit root to the unemployment rate.

In this paper, we take a closer look at the informational value of unemployment rates in studies of hysteresis. In particular, we apply a range of modern time-series methods to investigate whether the conclusions reached are sensitive to the use of employment rather than unemployment rates. If there indeed is a one-to-one relationship between unemployment and employment, as has commonly been assumed, the same conclusions will be reached regardless of which statistic is used. Despite the large interest in the functioning of labour markets, and the fact that most theories of labour-market hysteresis derive dynamic implications for the

\footnotetext{
${ }^{1}$ See for example Song and Wu (1997), Léon-Ledesma (2002) and Smyth (2003).
} 
behaviour of employment, testing for hysteresis with employment rates has received very little attention in the empirical literature. ${ }^{2}$ Whilst employment rates have their own drawbacks, they do provide a useful complement to unemployment rates in addressing the question of hysteresis.

The focus of the analysis is the functioning of labour markets in Australia, Austria, Canada, Finland, Sweden, the U.K. and the U.S.. Of these countries, Sweden and Finland tend toward more unionised and regulated labour markets, whereas the U.S. is at the other end of the spectrum (Cahuc and Zylberberg, 2004). With the exception of the U.K., the European countries in the sample are characterised by stronger unions and more regulated labour markets than Australia, Canada and the U.S..

In the next section, we present a standard insider-outsider model of the labour market and relate this to the concepts of employment and unemployment hysteresis. We then discuss the advantages and disadvantages of employment rates over unemployment rates. The empirical analysis in Section 3 shows that conclusions regarding hysteresis can depend on which measure is used. Consistent with previous studies, we find that evidence for unemployment hysteresis is mixed; results depend on which unit root test is applied, except for the U.K. where all tests agree on the presence of hysteresis. When analysing employment rates on the other hand, we find unequivocal evidence of employment hysteresis in Australia, Canada and U.S., but the evidence is mixed for the European countries. These findings contrast with previous results and question the conclusions drawn in earlier literature. Section 5 summarises our results.

\section{Employment rates and the theory of hysteresis}

\subsection{The definition of hysteresis}

Despite the frequent use of the term hysteresis in the labour-market literature since its introduction by Blanchard and Summers (1986), there exists no consensus definition thereof. One of few agreed-upon implications is that hysteresis is inconsistent with a constant natural

\footnotetext{
2 To our knowledge, the only related study is that of Burda (1990). That study, however, was conducted only on a number of Western European countries and focused on employment levels rather than the working-age population rate of employment.
} 
rate of unemployment. The natural-rate hypothesis - pioneered by Phelps (1967) and Friedman (1968) and with its starting point in the doctrine of monetary neutrality of unemployment states that deviations from a natural rate should be temporary and, under the assumption of a constant natural rate, the unemployment rate should accordingly be a mean reverting process. Whilst being the dominating theory in the field for some time, its inability to explain lasting high unemployment rates in Europe during the 1970s and 1980s drew criticism. Faced with what appeared to be a constant higher level of unemployment, researchers turned to alternative explanations.

The most prominent of these explanations was labour-market hysteresis. Blanchard and Summers (1986) initially loosely described hysteresis as a high degree of dependence of the current employment level on the past. Using their definition, it is sufficient that the sum of the autoregressive coefficients in a linear model is close to - but not necessarily equal to - one. This definition was also employed by Layard et al. (1991), who called the special case of a unit root in the time series pure hysteresis. However, in a substantial part of the later literature, the term hysteresis has become synonymous with a unit root in the unemployment rate. ${ }^{3}$ To further add to the confusion regarding terminology, there is also a part of the literature that defines hysteresis as a non-linear phenomenon allowing for multiple stable equilibria; see, for example, Amable et al. (1995) and Ljunqvist and Sargent (1998). Such models imply that whilst some shocks have only temporary effects, others will be permanent as they push the economy to the path of a new equilibrium. ${ }^{4}$ This paper will, however, join the part of the literature which interprets hysteresis as a unit root in a linear univariate model; the more elaborate non-linear model will not be the focus here.

\subsection{Insider-outsider models of hysteresis}

That no prior study has investigated whether the aggregate employment rate has a unit root is surprising given that most theoretical models of hysteresis derive expressions for the dynamics of employment rather than unemployment and that a majority of empirical studies claim to find their motivation in theoretical models along the lines of that in Blanchard and Summers (1986) and Gottfries and Horn (1987). ${ }^{5}$ In these models, employment may follow a random walk since

\footnotetext{
${ }^{3}$ See, for example, Røed (1996) and León-Ledesma (2002).

${ }^{4}$ For a further discussion on the topic of definitions of labour market hysteresis and its causes, the reader is referred to the survey by Røed (1997).

${ }^{5}$ See for instance McCausland (1998) and Léon-Ledesma (2002).
} 
insiders, who do not care about the utility of outsiders, dominate the wage bargaining. To clarify our point, we recapitulate the main conclusion of Blanchard and Summers' original model. ${ }^{6}$

All variables in the following are expressed as logarithms. The demand facing firm $i$ in period $t$ is given by

$y_{i t}=\left(m_{t}-p_{t}\right)-a\left(p_{i t}-p_{t}\right), \quad a>1$,

where $y_{i t}$ and $p_{i t}$ are the firm's output and nominal price, $m_{t}$ is nominal money, and $p_{t}$ the aggregate price level. Each firm's production function has constant returns to scale in which labour is the only argument. Hence $y_{i t}=n_{i t}$, where $n_{i t}$ is employment in firm $i$. Given constant marginal cost and constant elasticity of demand, profit maximisation implies $p_{i t}=w_{i t}$, where $w_{i t}$ is the nominal wage paid by firm $i$. Based on these relationships, and recognising that $p_{t}=w_{t}$, the derived demand for labour by firm $i$ is

$n_{i t}=\left(m_{t}-w_{t}\right)-a\left(w_{i t}-w_{t}\right)$.

Each firm $i$ is associated with a group of workers, $n_{i}^{*}$, organised in a firm-specific union. Unions are sufficiently strong to set wages unilaterally, and only the interests of the members are under consideration when doing so. Members also receive priority in employment - only when all members are employed are jobs open to non-members.

Unions set wages before nominal money is known and the wage is chosen to set expected employment according to the relationship

$E\left(n_{i t}\right)=(1-\rho) n_{i}^{*}+\rho n_{i t-1}$,

where $0 \leq \rho \leq 1$ denotes the weight attached to unemployed members. In the extremes, when $\rho$ equals zero, wages are set in order to equate expected employment with membership,

\footnotetext{
${ }^{6}$ To keep the model tractable but concise, we have made some simplifications to Blanchard and Summers (1986). These do not affect the main conclusions from the model concerning the dynamics of employment.
} 
whereas the union only covers the interests of currently employed members when $\rho$ equals unity.

Equations (2) and (3) imply that the nominal wage satisfies

$E\left(m_{t}\right)-E\left(w_{t}\right)-a\left[w_{i t}-E\left(w_{t}\right)\right]=(1-\rho) n_{i}^{*}+\rho n_{i t-1}$.

Assuming that all firms and groups of workers are the same and that the only shocks are aggregate nominal shocks, all firm-specific unions choose the same nominal wage. Hence, $w_{i t}=w_{t}=E\left(w_{t}\right)$. Substituting this into equation (2) yields the result that aggregate employment evolves according to $n_{t}=(1-\rho) n^{*}+\rho n_{t-1}+\left[m_{t}-E\left(m_{t}\right)\right]$. Assuming that shocks to money supply are iid, this can be rewritten as

$n_{t}=(1-\rho) n^{*}+\rho n_{t-1}+\varepsilon_{t}$,

where $\varepsilon_{t} \sim \operatorname{iid}\left(0, \sigma_{\varepsilon}^{2}\right)$. Equation (5) shows that if $\rho$ is equal to unity, employment exhibits a unit root.

Clearly, Blanchard and Summers’ model applies to employment, not unemployment. Only if there is a one-to-one relationship between unemployment and employment can $n_{t}$ and $n_{t-1}$ in (5) be replaced by their unemployment counterparts. Still, most studies find their motivation in equation (5) and then proceed to test unemployment dynamics assuming a constant labour supply, an assumption unlikely to be valid due to entry and exit from the labour force. ${ }^{7}$

\subsection{Should we prefer employment rates to unemployment rates?}

Given the representative insider-outsider model presented in Section 2.2, it is relevant to ask why previous studies of hysteresis have focused solely on unemployment rates, thereby imposing the assumption of a constant labour supply. We believe that part of the answer is to

\footnotetext{
${ }^{7}$ In addition to insider-outsider models, alternative explanations for hysteresis have been offered. Among the different theories, Phelps (1972) and Pissarides (1992) stress the possibility of human capital depreciation during unemployment as a mechanism through which one-time shocks could have permanent effects. But if long unemployment spells cause withdrawals from the labour force, the unemployment rate is uninformative also in this setting.
} 
be found in data availability. When data for numerous countries spanning a long time period are needed - as is often the case in this literature - unemployment rates tend to be more easily available.

However, employments rates are, of course, not without drawbacks. In particular, the large increase in female labour-force participation in most OECD countries during recent decades could render employment rates inappropriate if the purpose of a study is to investigate the dynamics of the number of individuals who want a job. That is, if women have entered the labour force directly into employment, employment rates will imply that the number of individuals who want but cannot find a job has steadily declined. However, due to social norms many women forty years ago probably did not want a job.

The drawbacks of employment rates when testing for a unit root among those who seek a job do not automatically make the unemployment rate a better measure for this purpose. As argued in the introduction, only individuals who are defined as actively searching for a job are recorded as unemployed, which in turn implies that the dynamics of unemployment rates will be affected by "artificial” changes in labour-force participation. This view is supported by the findings of Juhn et al. (1991, 2002) and Benati (2001) that shifts in labour-force participation occur for market-driven reasons, so called "discouraged-worker effects". 8 This is typically thought of as unemployed individuals reducing their search effort because of poor job prospects, but a "reversed discouraged-worked effect” may also operate, in which better labour market opportunities attract more individuals into the labour force. The poor informational value of unemployment rates is also strongly supported by Murphy and Topel (1997, p. 295) who argue that "the unemployment rate has become progressively less informative about the state of the labour market” because of important discouraged-worker effects among low skilled men in the U.S..

Whilst the research cited above applies to the U.S. labour market, important changes during recent decades raise similar reasons to mistrust the informational value of the unemployment rates throughout the OECD area. First, as shown by OECD (1995), women are much more prone to leave the labour force in response to unemployment spells. Higher female participation rates over time will thus likely continuously decrease the informational value of

\footnotetext{
${ }^{8}$ Stephens (2002) also shows that individuals' labour-force status may shift in response to a change in the partner's labour market status, so called “added worker effects”.
} 
unemployment rates as they become contaminated by discouraged-worker effects. Second, during the last three decades, the ratio of employment to population has fallen for older men (55 to 64 years old) in every OECD country. A large proportion of non-employed older male workers have also left the labour force through early retirement, with the exit usually preceded by a period of unemployment. As shown by OECD (1992), the decline in labour-force participation for this group is thus due almost entirely to a decline in employment opportunities and may thus be viewed as a discouraged worker effect.

In our opinion, neither unemployment rates nor employment rates constitute perfect statistics when investigating the dynamics of the number of individuals who want a job. ${ }^{9}$ For this issue to be properly investigated, long enough time series containing better and internationally comparable statistical measures of who wants a job and who does not need to be developed.

When then should employment rates be preferred - or at least be used as a complement - to unemployment rates? As shown above, most formal models of hysteresis derive expressions for employment rather than unemployment rates, so there is clearly a theoretical argument for doing so. Furthermore, many studies have set out to test whether one-time shocks to employment, positive as well as negative, have permanent effects. In that case, using unemployment rates seems inferior to employment rates, even in the presence of the increase in female labour-force participation. Only if female and male labour markets were completely separated could the use of unemployment rates potentially be preferable. However, even though there are some gender patterns across industries, there is far from complete segregation. The relevance of a common market is also strengthened by the findings of Topel (1994) and Juhn and Kim (1999) that males and females are substitutes for each other in the U.S. labour market. Moreover, if female and male labour markets were completely separated, previous studies should consequently only have studied the unemployment rate among males, since the increase in female labour-force participation affects the dynamics of the total unemployment rate. Almost without exception though, studies of hysteresis focus on the total unemployment rate in the economy, thus implicitly recognising the common female and male labour market.

\footnotetext{
${ }^{9}$ There are several additional problem attached to time series of both unemployment and employment rates. One such is the trend towards increased part-time employment and unemployment in many OECD countries during the last 30 years; see OECD (1995) and Lemaître et al. (1997). Unfortunately, each country tends to have its own definition of what constitutes part-time work, which makes it intractable to correct for this in cross-country data; see Lemaître et al. (1997). Another example is the expansion of the educational system in most OECD-countries. This may, at least in the short-run, decrease both employment and unemployment rates, though we are not aware of any studies on this issue. Also, increased access to disability welfare could affect the informational value of both unemployment and unemployment statistic.
} 
Though the employment rate clearly appears preferable to the unemployment rate when it comes to the question of whether one-time shocks to employment have permanent effects, it does not mean that it is without potential problems. In particular, how should one view the increase in female employment, and how should this increase be incorporated into the empirical framework? We discuss this issue in more detail in association with the outline of the empirical analysis in the next section. Here we simply note that based on current research on changes in female labour-force participation, no clearcut answers to these questions exist; see, for example, Birch (2005) for a survey of the determinants of female labour supply in Australia. However, even in the presence of this drawback, testing for hysteresis in employment rates is at the very least a test of the assumption that the results for unemployment rates carry over to employment rates. Testing this assumption will in turn enable us to shed new light on the question of hysteresis.

\section{Empirical study}

The empirical analysis uses monthly data on unemployment and employment rates $-u_{t}$ and $e_{t}$ respectively - for Australia, Austria, Canada, Finland, Sweden, the U.K. and the U.S.. The common sample concludes in November 2004 but includes several different starting dates February 1977 for Australia, January 1976 for Austria, Canada and Finland, January 1970 for Sweden, February 1971 for the U.K. and January 1951 for the U.S.. Each sample is, however, sufficiently long for reliable empirical analysis. These seven countries are the ones remaining after having considered the trade-off between reasonable sample length and high sampling frequency. ${ }^{10}$ As shown by Choi and Chung (1995), the latter can be important in order to increase power in unit-root tests.

The unemployment rates are reported as the number of unemployed divided by the number of people in the labour force. The employment rate is defined as the share of the population aged 15 to 64 that is employed. Labour market data were collected from the EcoWin Pro and LABORSTA databases, Statistics Sweden and the U.K. Office for National Statistics. Population data used to construct employment rates were taken from the UN and U.S. Census Bureau, except for Sweden and the U.K. where employment rates were taken directly from

\footnotetext{
${ }^{10}$ The lack of employment data is a limiting factor for the number of countries in our study. Unemployment data by contrast is typically easily available for almost any country.
} 
Statistics Sweden and the U.K. Office for National Statistics. ${ }^{11}$ The unemployment and employment numbers for Australia, Canada, the U.K. and the U.S. have all been seasonally adjusted, whereas the Austrian, Finnish and Swedish data still have seasonal variation left in them. As will be seen below, this difference is not of importance to the results. Needless to say it will affect the order of the model required to describe the time series in question.

The data are plotted in Figures 1 and 2 below, which clearly indicate that the picture of the labour-market development depends on whether one studies employment or unemployment rates. For example, whilst the unemployment rate in Australia has decreased from 6.7 percent at the beginning of the sample to 5.2 percent in November 2004, the employment rate rose from 65.7 to 73.8 percent during the same period. Hence, the Australian employment rate implies a stronger development for the labour market than the unemployment rate shows. The same also applies to Canada and the U.S.. Whereas the Canadian unemployment rate was close to seven percent both in 1976 and 2004, the employment rate rose from 63.5 to 72.3 percent over the same time span. This implies a substantial decrease in what might be described as the labour-market dependency ratio, that is, the share of people in working age in the economy who rely on someone else (through private or public means) for their provision. In contrast, the Austrian unemployment and employment rates have increased largely in tandem. In line with the arguments in Gustavsson and Österholm (2006), these differences highlight that it is important to consider labour-force participation before drawing conclusions based on unemployment rates.

\footnotetext{
${ }^{11}$ As the population data were available at an annual frequency, this was converted into monthly observations using simple linear interpolation. This appears to be a reasonable approximation when looking at monthly data given by the U.S. Census Bureau; for example, data between two consecutive December observations are extremely well described by a linear function. Also, changes in employment rates should almost completely be driven by employment rather than misspecified seasonal patterns for population numbers.
} 
Figure 1. Unemployment rates (percent).
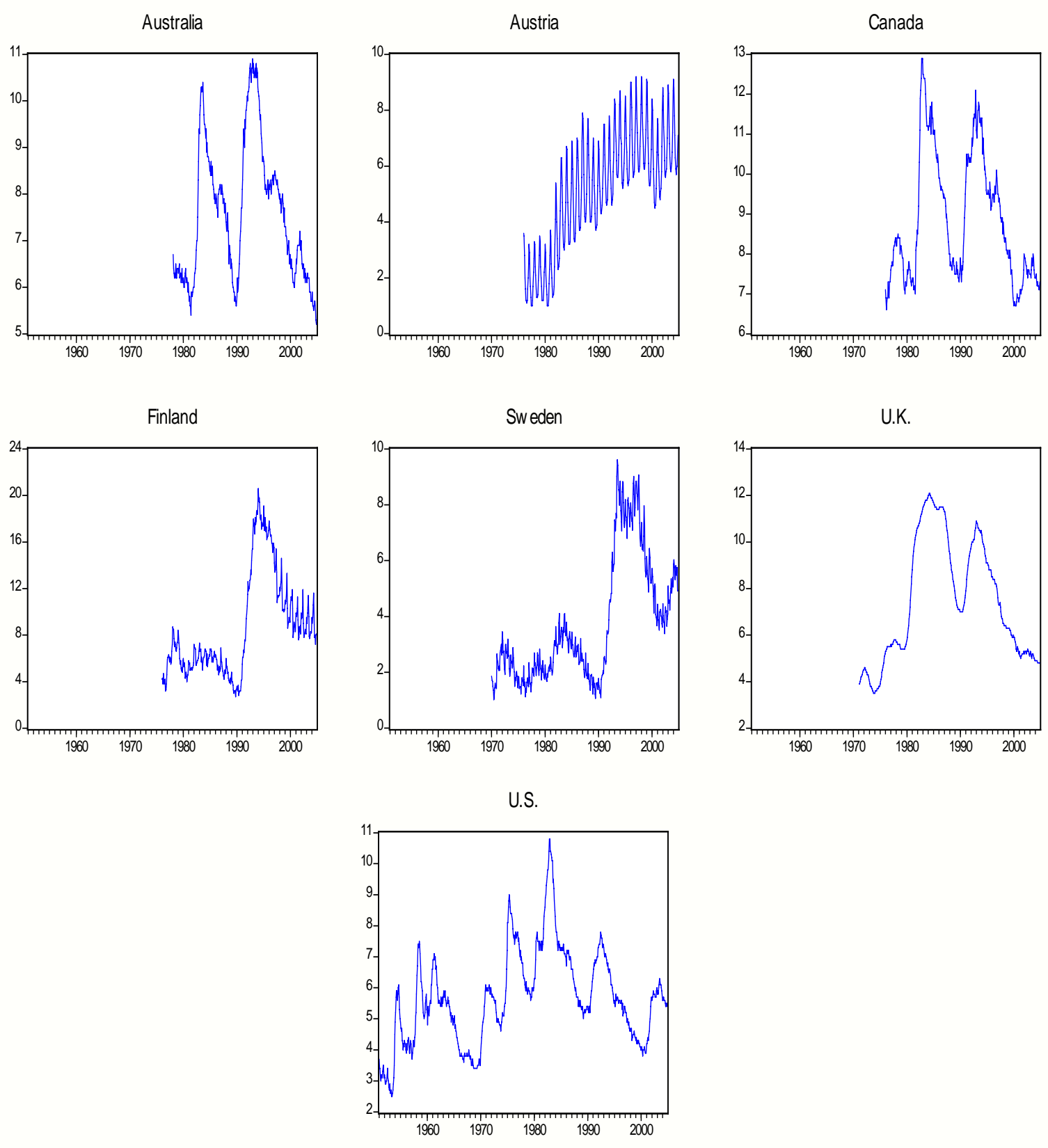

Note: Data for Austria, Finland and Sweden have not been seasonally adjusted. 
Figure 2. Employment rate (percent)
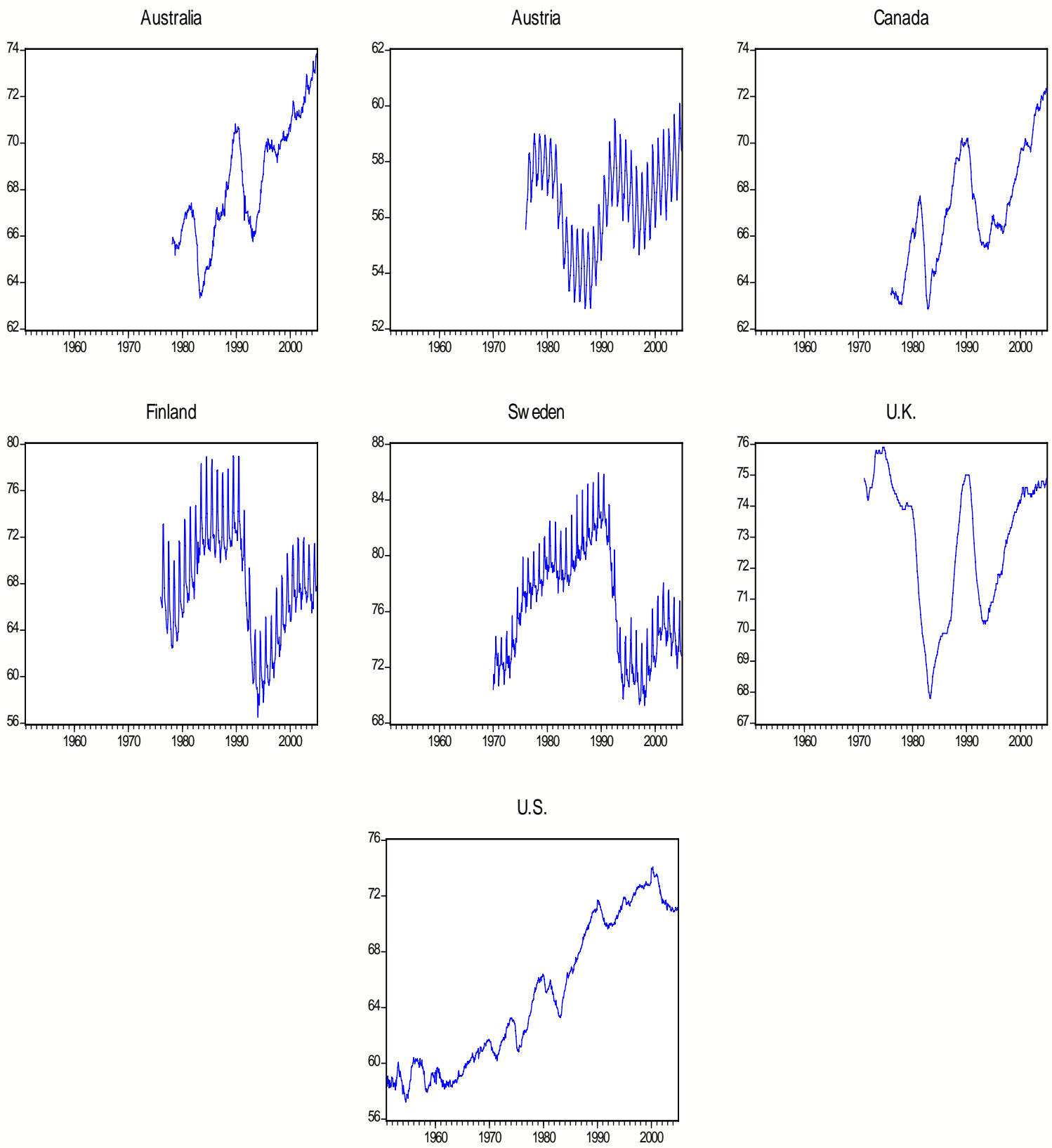

Note: Data for Austria, Finland and Sweden have not been seasonally adjusted.

Turning to the question of hysteresis, we will initially investigate the time-series properties of unemployment rates. This has been done in a large number of previous studies and will therefore not be the main focus of our paper. Rather, it is included as a preliminary finding and will serve as a reference point for the univariate unit-root tests on employment rates. Regarding 
the specification of the tests, we test only for mean reversion around a constant level and disregard specifications with a deterministic term. ${ }^{12}$

In order to test for unit roots in unemployment rates, we employ a battery of univariate tests; the Augmented Dickey-Fuller test (Said and Dickey, 1984), the Augmented Dickey-Fuller (ADF) test with GLS detrending (Elliot et al., 1996), the Kapetanios et al. (2003) test and KPSS (Kwiatkowski et al., 1992) test. The first three test whether the time series in question has a unit root versus the alternative hypothesis of stationarity; the KPSS test on the other hand has stationarity under the null, thereby reversing the burden of proof. The four unit root tests provide a reasonably wide range of different null and alternative hypotheses for a broad empirical investigation.

All tests except the Kapetanios et al. (2003) (KSS) test should be well known to the reader as they are frequently used in the literature; we will therefore only describe the KSS test in more detail. The test has been developed only recently and offers a way to test for potential nonlinear mean reversion, a data generating process which standard unit root tests tend to have poor power properties against. The test is based on estimation of

$$
\Delta x_{t}=\delta x_{t-1}^{3}+\sum_{j=1}^{s} \pi_{j} \Delta x_{t-j}+\psi_{t}
$$

where $x_{t}$ refers to demeaned values of the original time series, $\tilde{x}_{t}$ and $\psi_{t} \sim \operatorname{iid}\left(0, \sigma_{\psi}^{2}\right) .{ }^{13}$ For all time series under investigation, the null hypothesis $H_{0}: \delta=0$ is then tested versus $H_{1}: \delta<0$ using the $t$-statistic on $\hat{\delta}$. The null hypothesis of a unit root is rejected for small enough values of the test statistic; critical values can be found in Kapetanios et al. (2003).

In the ADF, ADF with GLS detrending (ADF-GLS) and Kapetanios et al. (KSS) tests, we must first determine lag length in the test equations. The Hannan-Quinn (1979) information criterion is used for this purpose; this criterion seems like the best compromise between the Schwarz (1978) criterion, which is well-known for choosing too low a lag length, and the Akaike (1974)

\footnotetext{
${ }^{12}$ As there is no theoretical reason to believe that unemployment rates should be trending over time, we argue that this is the only reasonable specification.

${ }^{13}$ The value of the delay parameter has been set to $d=1$; similar to Taylor et al. (2001), we argue that the delay parameter should be small.
} 
criterion, which lacks consistency properties and may be overly generous in modelling dynamics. Just like the Schwarz criterion, the Hannan-Quinn criterion is consistent in the sense that for large enough samples, it will choose the correct model given that the true model belongs to the set of models one is searching. Regarding lag length in the KSS test regressions, this is set equal to that of the ADF test; as pointed out by Kapetanios et al. (2003), linear dynamics can be seen as a first-order approximation if the true augmentations are non-linear in nature. The KPSS test is employed with a Newey-West estimator to correct for serial correlation.

A technical detail worth mentioning in the analysis of both unemployment rates and employment rates is that we also look at the time-series properties of the logistic transformation of the variables, that is, the variables $\tilde{u}_{t}=\ln \left(u_{t} /\left(1-u_{t}\right)\right)$ and $\tilde{e}_{t}=\ln \left(e_{t} /\left(1-e_{t}\right)\right)$ also have the unit-root tests applied to them. ${ }^{14}$ This sensitivity analysis is motivated by the econometric criticism that a variable that is bounded between zero and one strictly speaking cannot be a linear unit-root process with an additive error term fulfilling standard assumptions; ${ }^{15}$ the transformations $\tilde{u}_{t}$ and $\tilde{e}_{t}$, on the other hand, are unbounded above and below. This criticism has, almost without exception, been neglected in previous empirical work.

\footnotetext{
${ }^{14}$ Using the logistic transformation for bounded data was originally suggested by Wallis (1987).

${ }^{15}$ See Nicolau (2002).
} 
Table 1. Univariate unit-root tests on individual unemployment rates

\begin{tabular}{|c|c|c|c|c|c|c|c|}
\hline Country & Variable & ADF & $\begin{array}{l}\text { ADF- } \\
\text { GLS }\end{array}$ & KSS & KPSS & Sample & Lag length \\
\hline \multirow[t]{2}{*}{ Australia } & $u_{t}$ & -2.707 & $-2.463^{*}$ & -2.867 & 0.258 & $\begin{array}{l}\text { 1978:2- } \\
\text { 2004:11 }\end{array}$ & $(6,6,6)$ \\
\hline & $\ln \left(u_{t} /\left(1-u_{t}\right)\right)$ & -1.980 & -1.842 & -2.251 & 0.265 & $\begin{array}{l}\text { 1978:2- } \\
\text { 2004:11 }\end{array}$ & $(14,14,14)$ \\
\hline \multirow[t]{2}{*}{ Austria } & $u_{t}$ & -1.953 & -0.755 & -1.958 & $2.022^{* *}$ & $\begin{array}{l}\text { 1976:1- } \\
2004: 11\end{array}$ & $(15,15,15)$ \\
\hline & $\ln \left(u_{t} /\left(1-u_{t}\right)\right)$ & -2.557 & -1.580 & $-3.752^{* *}$ & $1.874^{* *}$ & $\begin{array}{l}\text { 1976:1- } \\
\text { 2004:11 }\end{array}$ & $(15,15,15)$ \\
\hline \multirow[t]{2}{*}{ Canada } & $u_{t}$ & -2.276 & -1.563 & $-3.278^{*}$ & 0.290 & $\begin{array}{l}\text { 1976:1- } \\
\text { 2004:11 }\end{array}$ & $(4,4,4)$ \\
\hline & $\ln \left(u_{t} /\left(1-u_{t}\right)\right)$ & -2.240 & -1.472 & $-3.009^{*}$ & 0.297 & $\begin{array}{l}\text { 1976:1- } \\
\text { 2004:11 }\end{array}$ & $(4,4,4)$ \\
\hline \multirow[t]{2}{*}{ Finland } & $u_{t}$ & $-3.218^{*}$ & $-2.461^{*}$ & $-3.887^{* *}$ & $0.906^{* *}$ & $\begin{array}{l}\text { 1976:1- } \\
\text { 2004:11 }\end{array}$ & $(14,14,14)$ \\
\hline & $\ln \left(u_{t} /\left(1-u_{t}\right)\right)$ & -2.597 & -1.773 & -2.785 & $0.994^{* *}$ & $\begin{array}{l}\text { 1976:1- } \\
\text { 2004:11 }\end{array}$ & $(16,16,16)$ \\
\hline \multirow[t]{2}{*}{ Sweden } & $u_{t}$ & -1.960 & -1.409 & -2.766 & $1.386^{* *}$ & $\begin{array}{l}\text { 1970:1- } \\
\text { 2004:11 }\end{array}$ & $(16,16,16)$ \\
\hline & $\ln \left(u_{t} /\left(1-u_{t}\right)\right)$ & -2.624 & -1.538 & $-3.025^{*}$ & $1.491^{* *}$ & $\begin{array}{l}\text { 1970:1- } \\
\text { 2004:11 }\end{array}$ & $(14,16,14)$ \\
\hline \multirow[t]{2}{*}{ U.K. } & $u_{t}$ & -2.037 & -1.291 & -1.926 & $0.521^{*}$ & $\begin{array}{l}\text { 1971:2- } \\
\text { 2004:11 }\end{array}$ & $(5,5,5)$ \\
\hline & $\ln \left(u_{t} /\left(1-u_{t}\right)\right)$ & -1.860 & -1.079 & -2.102 & $0.587^{*}$ & $\begin{array}{l}\text { 1971:2- } \\
\text { 2004:11 }\end{array}$ & $(5,5,5)$ \\
\hline \multirow[t]{2}{*}{ U.S. } & $u_{t}$ & $-3.544^{* *}$ & $-2.024^{*}$ & -2.778 & $0.626^{*}$ & $\begin{array}{l}\text { 1951:1- } \\
\text { 2004:11 }\end{array}$ & $(4,4,4)$ \\
\hline & $\ln \left(u_{t} /\left(1-u_{t}\right)\right)$ & $-2.882^{*}$ & -1.312 & -2.695 & $0.698^{*}$ & $\begin{array}{l}\text { 1951:1- } \\
\text { 2004:11 }\end{array}$ & $(12,12,12)$ \\
\hline $\begin{array}{l}5 \% \text { critical } \\
\text { value }\end{array}$ & & -2.87 & -1.94 & -2.93 & 0.46 & & \\
\hline
\end{tabular}

ADF is the test statistic from the Augmented Dickey-Fuller test.

ADF-GLS is the test statistic from the Augmented Dickey-Fuller test with GLS detrending.

KSS is the test statistic from the KSS test.

KPSS is the test statistic from the KPSS test

Lag length $(x, y, z)$ refers to the lag length used in the ADF, ADF-GLS and KSS tests respectively.

In all tests is mean reversion around a constant level tested for.

${ }^{* *}$ significant at the $1 \%$ level; ${ }^{*}$ significant at the $5 \%$ level 
The results from the unit-root tests on the seven unemployment rates are given in Table 1 . The evidence is mixed for all countries except for the U.K. where the unemployment rate is unanimously judged to be generated by a unit root process regardless of test and transformation of the data. It appears that the findings are somewhat sensitive to which transformation of the data is used. For Finland, for example, three out of four tests support a stationary unemployment rate when the original series is tested whereas there is no evidence of stationarity for the logistically transformed series. The evidence is also weakened - but less dramatically so - in Australia and the U.S. when the logistic transformation is used. In Austria and Sweden on the other hand, the complete absence of support for a stationary unemployment rate is slightly changed when the transformed data are used as the KSS test is then able to reject the unit root null.

Given the long controversy regarding the time-series properties of unemployment rates, these results are well in line with the previous mixed results in the literature. Depending on which tests the researcher prefers and which country and time period is being studied, the conclusions drawn can clearly differ. Despite the fact that univariate tests with a unit root under the null hypothesis are well known for their poor power against a stationary alternative when the process is near integrated, there is some evidence of stationarity in unemployment rates for all countries except for the U.K. even when these tests are used.

Having looked at unemployment rates, we next turn to the time-series properties of employment rates. Though the rise in female labour-force participation and employment during recent decades - and the declining participation and employment rates for older men during the same period - provide arguments for abandoning the unemployment rate when studying whether one-time shocks to employment have permanent effects, they also imply that one has to think carefully about how the unit-root tests should be conducted. In particular, should one view these changes as a series of shocks to employment or as deterministic trends?

Some might argue that there appears to be a deterministic trend in the some of the employment rates in Figure 2. We, however, do not think it appropriate to test for reversion around a linear trend, and for several reasons. First, the most important factor behind the increase in employment rates is increased employment among women. According to OECD (2002), the rise in female labour-force participation in the OECD area reflects complex interactions and 
feedbacks from a variety of socio-cultural, institutional, and economic factors. ${ }^{16}$ The view in the literature is thus that the career and participation decisions of women are complex and that no single explanation is likely to account for the changes. It should also be noted that changes in female participation in the OECD area in recent years have begun to resemble those of men with declining numbers (OECD, 2003). There are thus large difficulties forecasting changes in employment among women or older men, and it appears more sensible to model such events as a sequence of shocks. Second, the alternative of using a linear trend seems ad hoc and is done ex post to control for something that was very difficult to anticipate. It also raises the question of what to do if the net effect of changes in labour-force participation in the future generates a downward trend; most applied researchers are, for good reason, reluctant to use piecewise linear trends to account for such developments. Considering the above arguments, we conclude that the appropriate way to model changes in employment is as stochastic events rather than deterministic trends. This viewpoint can be interpreted as taking a methodological standpoint in line with the principle suggested by Cooley et al. (1982) that “... any entity which changes over time in a way that is not completely predictable should be modelled as a sequence of random variables".

Turning to the results of the univariate unit-root tests for employment rates shown in Table 2, we find that evidence is mixed in the four European countries. Evidence in favour of stationary employment rates is reasonably strong in both Austria and Finland, where three out of four tests support stationarity regardless of transformation of the data. The results for the U.K. provide more support for a unit-root process in the employment rate as only the KPSS test finds that the employment rate is stationary. The results for Sweden are least conclusive; evidence of a stationary employment rate is strong with the logistically transformed data but only the KSS test finds support for stationarity with the original data.

Keeping in mind the mixed evidence for the European countries in the sample, we next turn to the results for Australia, Canada and the U.S.. The evidence is far more conclusive for these three countries, with all four tests agreeing that there is no evidence of stationarity; as most

\footnotetext{
${ }^{16}$ As argued by Goldin and Katz (2000), one important factor for the increase in female labour-force participation in the U.S. during the recent decades was the increased availability of the birth-control pill during the early 1960s. "The pill" made it possible to increase the age at first marriage and thus made it easier to pursue professional education and training, which in turn increased the return from market work compared to non-market (household) work. Moreover, it seems to be clear that women's labour market decision are affected by the market conditions that they face; see Black and Juhn (2000). Part of the increase in female participation may thus be seen as a "reversed discouraged worker effect".
} 
researchers are well aware of, such a unanimous verdict from four different unit root tests is not very common in applied work on macroeconomic time series. Moreover, the results are insensitive to whether the original or logistically transformed data are tested. We argue that these results are very robust, as we have taken into account two potential pitfalls by using not only the traditional ADF and ADF-GLS tests - but also the KSS and KPSS tests, thereby allowing for both non-linear mean reversion and a reversed burden of proof respectively. Given that the same tests and sample periods were applied to unemployment rates, traditional objections to unit-root findings, namely poor power and size properties of the unit-root tests, do not seem compelling here. 
Table 2. Univariate unit-root tests on individual employment rates

\begin{tabular}{|c|c|c|c|c|c|c|c|}
\hline Country & Variable & ADF & $\begin{array}{l}\text { ADF- } \\
\text { GLS }\end{array}$ & KSS & KPSS & Sample & Lag length \\
\hline \multirow[t]{2}{*}{ Australia } & $e_{t}$ & -0.865 & 0.028 & -0.859 & $1.603^{* *}$ & $\begin{array}{l}\text { 1978:2- } \\
\text { 2004:11 }\end{array}$ & $(6,6,6)$ \\
\hline & $\ln \left(e_{t} /\left(1-e_{t}\right)\right)$ & -0.724 & 0.161 & -0.582 & $1.610^{* *}$ & $\begin{array}{l}\text { 1978:2- } \\
\text { 2004:11 }\end{array}$ & $(6,6,6)$ \\
\hline \multirow[t]{2}{*}{ Austria } & $e_{t}$ & $-3.512^{* *}$ & $-3.099^{* *}$ & -2.896 & 0.420 & $\begin{array}{l}\text { 1976:1- } \\
2004: 11\end{array}$ & $(13,13,13)$ \\
\hline & $\ln \left(e_{t} /\left(1-e_{t}\right)\right)$ & $-3.511^{* *}$ & $-3.092^{* *}$ & -2.886 & 0.420 & $\begin{array}{l}\text { 1976:1- } \\
\text { 2004:11 }\end{array}$ & $(13,13,13)$ \\
\hline \multirow[t]{2}{*}{ Canada } & $e_{t}$ & -1.198 & 0.023 & -1.199 & $1.297^{* *}$ & $\begin{array}{l}\text { 1976:1- } \\
\text { 2004:11 }\end{array}$ & $(3,3,3)$ \\
\hline & $\ln \left(e_{t} /\left(1-e_{t}\right)\right)$ & -1.103 & 0.096 & -1.033 & $1.294^{* *}$ & $\begin{array}{l}\text { 1976:1- } \\
\text { 2004:11 }\end{array}$ & $(3,3,3)$ \\
\hline \multirow[t]{2}{*}{ Finland } & $e_{t}$ & $-3.059^{*}$ & $-2.885^{* *}$ & $-3.637^{* *}$ & $0.523^{*}$ & $\begin{array}{l}\text { 1976:1- } \\
\text { 2004:11 }\end{array}$ & $(16,16,16)$ \\
\hline & $\ln \left(e_{t} /\left(1-e_{t}\right)\right)$ & $-3.615^{* *}$ & $-3.403^{* *}$ & $-4.019^{* *}$ & $0.531^{*}$ & $\begin{array}{l}\text { 1976:1- } \\
\text { 2004:11 }\end{array}$ & $(14,14,14)$ \\
\hline \multirow[t]{2}{*}{ Sweden } & $e_{t}$ & -2.740 & -1.558 & $-3.504^{* *}$ & $0.562^{*}$ & $\begin{array}{l}\text { 1970:1- } \\
\text { 2004:11 }\end{array}$ & $(16,16,16)$ \\
\hline & $\ln \left(e_{t} /\left(1-e_{t}\right)\right)$ & $-3.285^{*}$ & $-2.016^{*}$ & $-3.642^{* *}$ & $0.551^{*}$ & $\begin{array}{l}\text { 1970:1- } \\
\text { 2004:11 }\end{array}$ & $(14,14,14)$ \\
\hline \multirow[t]{2}{*}{ U.K. } & $e_{t}$ & -2.099 & -1.694 & -2.260 & 0.362 & $\begin{array}{l}\text { 1971:2- } \\
\text { 2004:11 }\end{array}$ & $(4,4,4)$ \\
\hline & $\ln \left(e_{t} /\left(1-e_{t}\right)\right)$ & -2.316 & -1.647 & -2.510 & 0.367 & $\begin{array}{l}\text { 1971:2- } \\
\text { 2004:11 }\end{array}$ & $(6,4,6)$ \\
\hline \multirow[t]{2}{*}{ U.S. } & $e_{t}$ & -1.000 & 0.705 & -1.225 & $3.203^{* *}$ & $\begin{array}{l}\text { 1951:1- } \\
\text { 2004:11 }\end{array}$ & $(4,4,4)$ \\
\hline & $\ln \left(e_{t} /\left(1-e_{t}\right)\right)$ & -0.587 & 0.832 & -1.206 & $2.899^{* *}$ & $\begin{array}{l}\text { 1951:1- } \\
\text { 2004:11 }\end{array}$ & $(4,4,4)$ \\
\hline $\begin{array}{l}5 \% \text { critical } \\
\text { value }\end{array}$ & & -2.87 & -1.94 & -2.93 & 0.46 & & \\
\hline
\end{tabular}

ADF is the test statistic from the Augmented Dickey-Fuller test.

ADF-GLS is the test statistic from the Augmented Dickey-Fuller test with GLS detrending.

KSS is the test statistic from the KSS test.

KPSS is the test statistic from the KPSS test

Lag length $(x, y, z)$ refers to the lag length used in the ADF, ADF-GLS and KSS tests respectively.

In all tests is mean reversion around a constant level tested for.

${ }^{* *}$ significant at the $1 \%$ level; ${ }^{*}$ significant at the $5 \%$ level

The combined finding of no evidence in favour of stationary employment rates in Australia, Canada and the U.S. but mixed evidence in the four European countries at face value seems surprising given that unemployment hysteresis has to a large extent has been described as a 
European phenomenon. Because of this, we will conduct some further sensitivity analysis to assess whether any evidence of stationarity in employment rates can be found for these three countries.

As pointed out by Perron (1989), the power of Dickey-Fuller type tests is known to be low when structural breaks are present in the time series. As a result, unit-root tests that allow for structural breaks - such as Perron (1989), Zivot and Andrews (1992), Clemente et al. (1998) and Vogelsang and Perron (1998) - have become popular in applied work, despite welldocumented shortcomings. ${ }^{17}$ From simple visual inspection of the Australian, Canadian and U.S. employment rates, there is little reason to believe that a structural break has taken place and institutional history confirms this opinion, there being few events which would qualify as structural breaks. Nonetheless, we shall test for such breaks to ensure our conclusions are robust to the possibility.

The tests that we employ are the Zivot and Andrews and Clemente el al. (CMR) tests allowing respectively for one and two endogenously determined breakpoint(s) in the intercept. Lag length in the Zivot and Andrews test equation is based on information criteria, but determined with a sequence of $F$-tests for the CMR test. Results from the tests are shown in Table 3 below, and it is evident that the null hypothesis of a unit root in the time series cannot be rejected for any of the three countries. Thus, allowing for structural breaks in our time series does not lead us to alter our conclusions regarding the time-series properties of the Australian, Canadian and U.S. employment rates. ${ }^{18}$

\footnotetext{
${ }^{17}$ One well-known problem is the risk of spurious rejection of the null hypothesis when the breakpoint is chosen endogenously; see for example Nunes et al. (1997), Vogelsang and Perron (1998) and Lee and Strazicich (2001). Determining the number of breaks is also problematic - see, for example, Nunes et al. (1996) - as is locating the timing of the break (Lee and Strazicich, 2001).

${ }^{18}$ Results for unemployment and employment rates for all seven countries (not reported, but available upon request) show that there is typically weak evidence of stationarity using these tests. In fact, there is only evidence of mean reversion for Austrian and Finnish unemployment rates and Austrian, Finnish and Swedish employment rates using the Zivot and Andrews test. For the CMR test, no evidence of stationarity can be found in any case. One likely explanation for these results is that structural breaks are not a common feature of the time series under consideration. Allowing for structural breaks when there are none may reduce the power of the tests because of the inclusion of redundant regressors in the test equation and the fact that critical values are larger in absolute terms.
} 
Table 3. Univariate unit root tests allowing for strctural breaks

\begin{tabular}{|c|c|c|c|c|c|c|}
\hline \multirow[t]{2}{*}{ Country } & \multirow[t]{2}{*}{ Variable } & \multirow{2}{*}{$\begin{array}{c}\text { Zivot } \\
\text { and } \\
\text { Andrews }\end{array}$} & \multicolumn{2}{|c|}{ CMR } & \multirow{2}{*}{$\begin{array}{l}\text { Lag } \\
\text { length }\end{array}$} & \multirow[t]{2}{*}{ Sample } \\
\hline & & & AO & IO & & \\
\hline \multirow[t]{2}{*}{ Australia } & $e_{t}$ & -2.949 & -3.067 & -3.064 & $(3,6,12)$ & $\begin{array}{l}\text { 1978:2- } \\
\text { 2004:11 }\end{array}$ \\
\hline & $\ln \left(e_{t} /\left(1-e_{t}\right)\right)$ & -2.944 & -2.243 & -2.914 & $(3,2,12)$ & $\begin{array}{l}\text { 1978:2- } \\
\text { 2004:11 }\end{array}$ \\
\hline \multirow[t]{2}{*}{ Canada } & $e_{t}$ & -4.071 & -2.664 & -3.142 & $(3,1,3)$ & $\begin{array}{l}\text { 1976:1- } \\
\text { 2004:11 }\end{array}$ \\
\hline & $\ln \left(e_{t} /\left(1-e_{t}\right)\right)$ & -4.044 & -2.690 & -3.054 & $(3,1,3)$ & $\begin{array}{l}\text { 1976:1- } \\
\text { 2004:11 }\end{array}$ \\
\hline \multirow[t]{2}{*}{ U.S. } & $e_{t}$ & -3.995 & -3.761 & -4.397 & $(4,0,12)$ & $\begin{array}{l}\text { 1951:1- } \\
\text { 2004:11 }\end{array}$ \\
\hline & $\ln \left(e_{t} /\left(1-e_{t}\right)\right)$ & -3.994 & -3.770 & -4.378 & $(4,0,12)$ & $\begin{array}{l}\text { 1951:1- } \\
\text { 2004:11 }\end{array}$ \\
\hline $\begin{array}{l}5 \% \text { critical } \\
\text { value }\end{array}$ & & -4.80 & -5.49 & -5.49 & & \\
\hline
\end{tabular}

Zivot and Andrews is the test statistic from the Zivot and Andrews test.

CMR is the test statistic from the Clemente et al. test; AO is the test under the assumption of additive outliers; IO is the test under the assumption of innovational outliers.

Lag length $(x, y, z)$ refers to the lag length used in the Andrews and Zivot, CMR-AO and CMR-IO tests respectively.

Mean reversion around levels are tested for.

** significant at the 1\% level; " significant at the $5 \%$ level

In a last attempt to overthrow our finding of a unit root in the employment rates of Australia, Canada and the U.S., we turn to the heavy artillery of unit-root testing: panel unit-root tests. Panel unit-root tests, such as the Multivariate Augmented Dickey-Fuller test (Taylor and Sarno, 1998), the Levin and Lin test (Levin, Lin and Chu, 2002) and the Im, Pesaran and Shin (2003) test, have been shown to increase power compared to univariate unit root tests (Taylor and Sarno, 1998 and Im et al., 2003). ${ }^{19}$ Accordingly, such tests have been used in a large variety of empirical applications in macroeconomics, including Evans and Karrass (1996), O’Connell (1998) and Wu (2000).

\footnotetext{
19 The increase in power does not come without a cost, as the tests have some well-known drawbacks. For a discussion regarding the problems of panel unit root tests, see Maddala and Wu (1999) and Österholm (2004).
} 
In this paper the Im, Pesaran and Shin (2003), Johansen (1988) likelihood ratio and Hadri (2000) LM tests are applied to the panel consisting of Australia, Canada and the U.S.. ${ }^{20}$ These tests are standard tools nowadays and will not be described in detail here; instead the reader is referred to Im et al. (2003), Taylor and Sarno (1998) and Hadri (2000) respectively. The null hypothesis of the Im, Pesaran and Shin (IPS) test is that all time series are unit-root processes and the alternative hypothesis is that at least one of the time series is stationary. The Johansen likelihood ratio (JLR) test, on the other hand, tests the null hypothesis of at least one series being a unit root process against an alternative that all time series in the panel are stationary. Finally, the Hadri LM test is a panel version of the KPSS test. Its null hypothesis is that all time series in the panel are stationary and this is tested against the alternative of all series being unit-root processes.

For the IPS and JLR tests, lag length must be chosen. As the IPS test is based on pooled univariate ADF tests, it seems reasonable to set the lag length in this test based on the maximum from the univariate tests. For the JLR test, the Hannan-Quinn information criterion is applied to the VAR in levels to establish lag length $(k)$; lag length in the vector error correction model, which forms the base for the test, is then set to $k-1$. For the Hadri LM test, serial correlation is addressed with a Newey-West estimator of the long-run variance.

Table 4 presents the results from the panel unit root tests on the three employment rates. Once again we test for mean reversion around a constant level and once again it is clear that the data offer no support for stationarity. The IPS and JLR tests are unable to reject their respective null hypotheses. Clearly, the cross-sectional dimension is small in this study so the power gains for the IPS and JLR tests are potentially minor. Taylor and Sarno (1998) and Österholm (2004), however, show that there are power gains to be made even in such cases. The Hadri LM test

\footnotetext{
${ }^{20}$ The Levin and Lin (LL) test - whilst reasonably popular in empirical work - has an alternative hypothesis of all series converging towards equilibrium at the same speed and this restriction is typically judged overly restrictive in most applications. It has also been shown by Maddala and Wu (1999) that both the IPS and the LL tests have fairly high power even if only one of the included series in a panel is stationary. Based on these observations and the fact that there is some evidence favouring stationarity of employment rates in each of the European countries - we choose not to use the LL test at all in the empirical analysis and to only include Australia, Canada and the U.S. in the panel. This setup means that we will be able to draw stronger conclusions from the panel unit root tests. For example, if the IPS test rejects its null hypothesis, it is in this case clear that at least one of the employment rates in Australia, Canada or the U.S. is stationary and that rejection was due to power gains from pooling. If on the other hand any of the employment rates that were judged stationary by the univariate tests had been included in the panel, rejection of the null of the IPS test would be highly likely to be due to that/those series and we would have gained no additional information regarding the employment rates in the non-European economies. See Léon-Ledesma (2002) for a similar approach to this issue.
} 
further confirms the absence of mean-reverting employment rates in Australia, Canada and the U.S., forcefully rejecting the null hypothesis of panel stationarity.

Table 4. Panel unit-root tests on Australian, Canadian and U.S. employment rates

\begin{tabular}{|c|c|c|c|c|c|}
\hline Variable & IPS & JLR & Hadri & Sample & Lag length \\
\hline $\begin{array}{c}e_{t} \\
\ln \left(e_{t} /\left(1-e_{t}\right)\right)\end{array}$ & $\begin{array}{l}-1.401 \\
-1.304\end{array}$ & $\begin{array}{l}1.081 \\
0.952\end{array}$ & $\begin{array}{l}52.573^{* *} \\
52.906^{* *}\end{array}$ & $\begin{array}{l}\text { 1978:2- } \\
\text { 2004:11 } \\
\text { 1978:2- } \\
\text { 2004:11 }\end{array}$ & $\begin{array}{l}(6,3) \\
(6,3)\end{array}$ \\
\hline $\begin{array}{l}5 \% \text { critical } \\
\text { value }\end{array}$ & -1.65 & 3.84 & 1.65 & & \\
\hline \multicolumn{6}{|c|}{$\begin{array}{l}\text { IPS is the t-bar test statistic from the Im, Pesaran and Shin test. } \\
\text { JLR is the test statistic from the Johansen likelihood ratio test. } \\
\text { Hadri is the test statistic from the Hadri LM test. } \\
\text { Lag length }(x, y) \text { refers to the lag length used in the IPS and JLR tests respectively. } \\
\text { In all tests is mean reversion around a constant level tested for. } \\
{ }^{* *} \text { significant at the } 1 \% \text { level; }{ }^{*} \text { significant at the } 5 \% \text { level }\end{array}$} \\
\hline
\end{tabular}

The Australian, Canadian and U.S. employment rates have by now been offered several chances to provide evidence of stationarity, but failed in every case. This leads us to our final conclusion that the time series properties of employment rates in Australia, Canada and the U.S. are best described as unit-root processes.

\section{Conclusion}

Knowing whether one-time shocks have permanent or transitory effects is crucial for understanding how labour markets function. In this paper we have shown that the answer can differ substantially depending on whether the question is approached with unemployment or employment rates. When unit root tests are applied to unemployment rates, we find mixed evidence for hysteresis for all countries but the U.K.; all tests unanimously conclude that the U.K. unemployment rate has been generated by a unit root process. Turning to employment rates on the other hand, the evidence is inconclusive for the four European countries. For Australia, Canada and the U.S., however, evidence of a unit root in employment rates is unequivocal. Labour markets in these countries are hence characterised by employment hysteresis. 
The results in this paper demonstrate the pitfalls of relying on unemployment rates in studies of hysteresis, and thus cast doubt on conclusions of previous studies. Most theoretical models of hysteresis derive expressions for random-walk behaviour of employment and results carry over to unemployment only when a constant labour supply is assumed. Previous empirical studies claim to have their foundation in these models but have used unemployment rates and thus explicitly or implicitly - assumed a one-to-one relation between employment and unemployment. Our results indicate that the assumption of a constant labour supply may be both false and a poor approximation to actual labour market behaviour; this implies that previous studies are likely to have reached incorrect conclusions regarding the functioning of labour markets.

In particular, our results are not easily reconciled with insider-outsider models along the lines of Blanchard and Summers (1986). In these models, unions and regulated labour markets are often the explicit or implicit causes of hysteresis, which does not fit well with the strong evidence for employment hysteresis in the relatively weakly unionised countries in our sample, Australia, Canada, and the U.S..

However, our findings do not imply that labour market institutions do not matter. Australia, Canada, and the U.S. generally have had more positive developments in their respective employment rates than the European countries, indicating that positive shocks to these countries have had permanent effects. Given similar positive shocks, it may be the institutional backdrop of the European countries included in this study that has resulted in only transitory effects. Employment hysteresis is not necessarily undesirable, but one must look beyond the standard union or insider-outsider models to explain the results found in this paper. Further research on the causes and consequences of hysteresis is therefore warranted. 


\section{References}

Akaike, H. (1974), “A New Look at Statistical Model Identification”, IEEE Transactions on Automatic Control 19, 716-723.

Amable, B., Henry, J., Lordon, F. and Topol, R. (1995), "Hysteresis Revisited: A Methodological Approach”, In: Cross, R. (ed), The Natural Rate of Unemployment. Cambridge University Press, Cambridge.

Andrews, D. W. K. and Zivot, E. (1992), "Further Evidence on the Great Crash, the Oil-Price Shock, and the Unit-Root Hypothesis", Journal of Business and Economics Statistics 10, 251-270.

Benati, L. (2001), “Some Empirical Evidence on the 'Discouraged Worker' Effect”, Economics Letters 70, 387-395.

Birch, E.-L. (2005), "Studies of the Labour Supply of Australian Women: What Have We Learned?”, Economic Record 81, 65-84.

Black, S. E. and Juhn, C (2000), “The Rise of Female Professionals: Are Women Responding to Skill Demand?”, American Economic Review 90, 450-455.

Blanchard, O. J. and Summers, L. H. (1986), "Hysteresis and the European Unemployment Problem”, NBER Macroeconomics Annual 1, 15-78.

Brandolini, A., Cipollone, P. and Viviano, E. (2006), "Does the ILO Definition Capture All Unemployment?”, Journal of the European Economic Association 4, 153-179.

Burda, M. C. (1990), "Some Evidence on the Membership Hysteresis Hypothesis in Europe”, Empirical Economics 15, 143-152.

Cahuc, P. and Zylberberg, A. (2004), Labor Economics, The MIT Press, Cambridge MA.

Choi, I. and Chung, B. S. (1995), "Sampling Frequency and the Power of Tests for a Unit Root: A Simulation Study”, Economics Letters 49, 131-136.

Clark, K. B. and Summers, L. H. (1979), "Labour Market Dynamics and Unemployment: A Reconsideration”, Brookings Papers on Economic Activity 1:1979, 13-63.

Clemente, J. Montañés, A. and Reyes, M. (1998), “Testing for a Unit Root with a Double Change in the Mean”, Economics Letters 59, 175-182.

Coleman, T. S. (1989), “Unemployment Behaviour, Evidence from the CPS Work Experience Survey”, Journal of Human Resources 24, 1-38

Cooley, T. F., LeRoy, S. F. and Raymon, N. (1982), "Modeling Policy Interventions”, Paper presented at North American Summer Meeting of the Econometric Society, June 1982, Ithaca, New York. 
Elliott, G., Rothenberg, T. J. and Stock, J. H. (1996), “Efficient Tests for an Autoregressive Unit Root”, Econometrica 64, 813-836.

Evans, P. and Karrass, G. (1996), "Do Economies Converge? Evidence from a Panel of U.S. States”, Review of Economics and Statistics 78, 384-388.

Feldstein, M. and Ellwood, S. T. (1982), “Teenage Unemployment: What is the Problem?”, In: Freeman, R. B. and Wise, D. A. (eds), The Youth Labor Market Problem: Its Nature, Causes and Consequences. NBER, Chicago.

Friedman, M. (1968), “The Role of Monetary Policy”, American Economic Review 58, 1-17.

Goldin, C. and Katz, L. F. (2000), "Career and Marriage in the Age of the Pill”, American Economic Review 90, 461-465

Gottfries, N. and Horn, H. (1987), "Wage Formation and the Persistence of Unemployment”, Economic Journal 97, 877-884.

Gustavsson, M. and Österholm, P. (2006), “The Informational Value of Unemployment Statistics: A Note on the Time Series Properties of Participation Rates”, Forthcoming in Economics Letters.

Hadri, K. (2000), “Testing for Stationarity in Heterogeneous Panel Data”, Econometrics Journal 3, 148-161.

Hannan, E. J. and Quinn, B. G. (1979), "The Determination of the Order of an Autoregression”, Journal of the Royal Statistical Society 41, 190-195.

Im, K. S., Pesaran, M. H. and Shin, Y. (2003), "Testing for Unit Roots in Heterogeneous Panels", Journal of Econometrics 115, 53-74.

Johansen, S. (1988), "Statistical Analysis of Cointegration Vectors", Journal of Economic Dynamics and Control 12, 231-254.

Juhn, C. and Kim, D. (1999), “The Effect of Rising Female Labor Supply on Male Wages”, Journal of Labor Economics 17, 23-48.

Juhn, C., Murphy, K. M., Topel, R. H. (1991), "Why Has the Natural Rate of Unemployment Increased over Time?”, Brookings Papers on Economic Activity 1:1991, 75-126.

Juhn, C., Murphy, K. M., Topel, R. H. (2002), "Current Unemployment, Historically Contemplated”, Brookings Papers on Economic Activity 1:2002, 79-116.

Kapetanios, G., Shin, Y. and Snell, A. (2003), “Testing for a Unit Root in the Nonlinear STAR Framework”, Journal of Econometrics 112, 359-379.

Kwiatkowski, D., Phillips, P. C. B., Schmidt, P. and Shin, Y. (1992), “Testing the Null Hypothesis of Stationarity Against the Alternative of a Unit Root: How Sure are We That Economic Time Series Have a Unit Root?”, Journal of Econometrics 54, 159178. 
Lemaître, G., Marianna, P. and van Bastelaer, A. (1997), “International Comparisons of PartTime Work”, OECD Economic Studies 29, 139-152.

Lee, J. and Strazicich, M. C. (2001), "Break Point Estimation and Spurious Rejections with Enodgenous Unit Root Tests”, Oxford Bulletin of Economics and Statistics 63, 535558.

León-Ledesma, M. A. (2002), "Unemployment Hysteresis in the US States and the EU: A Panel Approach”, Bulletin of Economic Research 54, 95-105.

Levin, A., Lin, C.-F. and Chu, C.-S. J. (2002), “Unit Root Tests in Panel Data: Asymptotic and Finite-Sample Properties”, Journal of Econometrics 108, 1-24.

Ljungqvist, L. and Sargent, T. (1998), “The European Unemployment Dilemma”, Journal of Political Economy 106, 514-550.

Maddala, G. S. And Wu, S. (1999), “A Comparative Study of Unit Root Tests with Panel Data and a New Simple Test”, Oxford Bulletin of Economics and Statistics 61, 631-652.

McCausland, W. D. (1998), "Employment Hysteresis in an Overlapping-Generations InsiderOutsider Model”, Australian Economic Papers 37, 394-403.

Murphy, K. M. and Topel, R. (1997), "Unemployment and Nonemployment”, American Economic Review 87, 295-300.

Nicolau, J. (2002), "Stationary Processes that Look like Random Walks - The Bounded Random Walk Process in Discrete and Continuous Time”, Econometric Theory 18, 99-118.

Nunes, L., Newbold, P. and Kuan, C.-M. (1996), “Spurious Number of Breaks”, Economics Letters 50, 175-178.

Nunes, L., Newbold, P. and Kuan, C.-M. (1997), "Testing for Unit Roots with Breaks: Evindence on the Great Crash and the Unit Root Hypothesis Reconsidered”, Oxford Bulletin of Economics and Statistics 59, 435-448.

O’Connell, P. G. J. (1998), “The Overvaluation of Purchasing Power Parity”, Journal of International Economics 44, 1-19.

OECD (1992), Employment Outlook, OECD, Paris.

OECD (1995), Employment Outlook, OECD, Paris.

OECD (2002), Employment Outlook, OECD, Paris.

OECD (2003), "Labour Force Participation of Groups at the Margin of the Labour Market: Past and Future Trends and Policy Changes”, Document prepared by the Economics Department for Working Party No. 1 of the Economic Policy Committee, OECD.

Österholm, P. (2004), “Testing for Hysteresis in the Nordic Countries Using the Johansen Likelihood Ratio Test for Cointegration”, Applied Economics Quarterly 50, 249-260. 
Perron, P. (1989), “The Great Crash, the Oil-Price Shock, and the Unit Root Hypothesis”, Econometrica 57, 1361-1401.

Phelps, E. S. (1972), Inflation Policy and Unemployment Theory: The Cost-Benefit Approach to Monetary Planning, Norton, New York.

Pissarides, C. (1992), "Loss of Skill during Unemployment and the Persistence of Employment Shocks”, Quarterly Journal of Economics 107, 1371-1391

Røed, K. (1996), “Unemployment Hysteresis”, Empirical Economics 21, 589-600.

Røed, K. (1997), “Hysteresis in Unemployment”, Journal of Economic Surveys 11, 389-418.

Said, S. E. and Dickey, D. A. (1984), "Testing for Unit Roots in Autoregressive Moving Average Models of Unknown Order”, Biometrika 71, 599-607.

Schwarz, G. (1978), "Estimating the Dimension of a Model”, Annals of Statistics 6, 461-464.

Smyth, R. (2003), ”Unemployment Hysteresis in Australian States and Territories: Evidence from Panel Data Unit Root Tests”, Australian Economic Review 36, 181-192.

Song, F. M. and Wu, Y. (1997), “Hysteresis in Unemployment: Evidence from 48 US States”, Economic Inquiry 35, 235-243.

Stephens, M. (2002), “Worker Displacement and the Added Worker Effect”, Journal of Labor Economics 20, 504-537.

Taylor, M. P., Peel, D. and Sarno, L. (2001), “Nonlinear Mean-Reversion in Real Exchange Rates: Toward a Solution to the Purchasing Power Parity Puzzles”, International Economic Review 42, 1015-1042.

Taylor, M. P. and Sarno L. (1998), “The Behaviour of Real Exchange Rates During the Post-Bretton Woods Period”, Journal of International Economics 46, 281-312.

Topel, R. (1994), "Regional Labor Markets and the Determinants of Wage Inequality", American Economic Review 82, 17-22.

Vogelsang, T. and Perron, P. (1998), “Additional Tests for a Unit Root Allowing for a Break in the Trend Function at an Unknown Time”, International Economic Review 39, 10731100 .

Wallis, K. (1987), “Time Series Analysis of Bounded Economic Variables”, Journal of Time Series Analysis 8, 115-123.

Wu, J. L. (2000), "Mean Reversion of the Current Account: Evidence From the Panel Data Unit-Root Test“, Economics Letters 66, 215-222.

Zivot, E. and Andrews, D. W. K. (1992), "Further Evidence on the Great Crash, the Oil-Price Shock and the Unit Root Hypothesis", Journal of Business and Economics Statistics $10,251-270$. 
WORKING PAPERS*

Editor: Nils Gottfries

2005:9 Olof Åslund and Peter Fredriksson, Ethnic Enclaves and Welfare Cultures Quasi-experimental Evidence. 37 pp.

2005:10 Annika Alexius and Erik Post, Exchange Rates and Asymmetric Shocks in Small Open Economies. 31 pp.

2005:11 Martin Ågren, Myopic Loss Aversion, the Equity Premium Puzzle, and GARCH. 34 pp.

2005:12 Pär Holmberg, Numerical Calculation of an Asymmetric Supply Function Equilibrium with Capacity Constraints. 18 pp.

2005:13 Jovan Zamac, Winners and Losers from a Demographic Shock under Different Intergenerational Transfer Schemes. 44 pp.

2005:14 Peter Welz and Pär Österholm, Interest Rate Smoothing versus Serially Correlated Errors in Taylor Rules: Testing the Tests. 29 pp.

2005:15 Helge Bennmarker, Kenneth Carling and Bertil Holmlund, Do Benefit Hikes Damage Job Finding? Evidence from Swedish Unemployment Insurance Reforms. 37 pp.

2005:16 Pär Holmberg, Asymmetric Supply Function Equilibrium with Constant Marginal Costs. 27 pp.

2005:17 Pär Holmberg: Comparing Supply Function Equilibria of Pay-as-Bid and Uniform-Price Auctions. 25 pp.

2005:18 Anders Forslund, Nils Gottfries and Andreas Westermark: Real and Nominal Wage Adjustment in Open Economies. 49 pp.

2005:19 Lennart Berg and Tommy Berger, The Q Theory and the Swedish Housing Market - An Empirical Test. 16 pp.

2005:20 Matz Dahlberg and Magnus Gustavsson, Inequality and Crime: Separating the Effects of Permanent and Transitory Income. 27 pp.

2005:21 Jenny Nykvist, Entrepreneurship and Liquidity Constraints: Evidence from Sweden. 29 pp.

2005:22 Per Engström, Bertil Holmlund and Jenny Nykvist: Worker Absenteeism in Search Equilibrium. 35pp.

2005:23 Peter Hästö and Pär Holmberg, Some inequalities related to the analysis of electricity auctions. 7pp.

\footnotetext{
* A list of papers in this series from earlier years will be sent on request by the department.
} 
2006:1 Jie Chen, The Dynamics of Housing Allowance Claims in Sweden: A discrete-time hazard analysis. 37pp.

2006:2 Fredrik Johansson and Anders Klevmarken: Explaining the size and nature of response in a survey on health status and economic standard. 25pp.

2006:3 Magnus Gustavsson and Henrik Jordahl, Inequality and Trust: Some Inequalities are More Harmful than Others. 29pp.

2006:4 N. Anders Klevmarken, The Distribution of Wealth in Sweden: Trends and Driving factors. 20pp.

2006:5 Erica Lindahl and Andreas Westermark: Soft Budget Constraints as a Risk Sharing Arrangement in an Economic Federation. 22pp.

2006:6 Jonas Björnerstedt and Andreas Westermark: Bargaining and Strategic Discrimination. 36pp.

2006:7 Mikael Carlsson, Stefan Eriksson and Nils Gottfries: Testing Theories of Job Creation: Does Supply Create Its Own Demand? 23pp.

2006:8 Annika Alexius and Erik Post, Cointegration and the stabilizing role of exchange rates. 33pp.

2006:9 David Kjellberg, Measuring Expectations. 46pp.

2006:10 Nikolay Angelov, Modellig firm mergers as a roommate problem. 21pp.

2006:11 Nikolay Angelov, Structural breaks in iron-ore prices: The impact of the 1973 oil crisis. 41pp.

2006:12 Per Engström and Bertil Holmlund, Tax Evasion and Self-Employment in a High-Tax Country: Evidence from Sweden. 16pp.

2006:13 Matias Eklöf and Daniel Hallberg, Estimating retirement behavior with special early retirement offers. 38pp.

2006:14 Daniel Hallberg, Cross-national differences in income poverty among Europe’s 50+. 24pp.

2006:15 Magnus Gustavsson and Pär Österholm, Does Unemployment Hysteresis Equal Employment Hysteresis? 27pp.

See also working papers published by the Office of Labour Market Policy Evaluation http://www.ifau.se/

ISSN 1653-6975 